\title{
An academic Arabic corpus for plagiarism detection: design, construction and experimentation
}

\author{
Eman Al-Thwaib ${ }^{1}$, Bassam H. Hammo ${ }^{2^{*}}$ and Sane Yagi ${ }^{3}$
}

\author{
* Correspondence: b.hammo@ju. \\ edu.jo \\ ${ }^{2}$ Computer Information Systems \\ Department, King Abdullah II \\ School of Information Technology, \\ University of Jordan, Amman, \\ Jordan \\ Full list of author information is \\ available at the end of the article
}

\begin{abstract}
Advancement in information technology has resulted in massive textual material that is open to appropriation. Due to researchers' misconduct, a plethora of plagiarism detection (PD) systems have been developed. However, most PD systems on the market do not support the Arabic language. In this paper, we discuss the design and construction of an Arabic PD reference corpus that is dedicated to academic language. It consists of (2312) dissertations that were defended by postgraduate students at the University of Jordan (JU) between the years 2001-2016. This Academic Jordan University Plagiarism Detection corpus; henceforth, JUPlag, follows the Dewey decimal classification (DDC) in the way it is structured. The goal of the corpus is twofold: Firstly, it is a database for the detection of plagiarism in student assignments, reports, and dissertations. Secondly, the n-gram structure of the corpus provides a knowledgebase for linguistic analysis, language teaching, and the learning of plagiarism-free writing. The PD system is guided by JU Library's metadata for retrieval and discovery of plagiarism. To test JUPlag, we injected an unseen dissertation with multiple instances of plagiarism-simulated paragraphs and sentences.

Experimentation with the system using different verbatim n-gram segments is indeed promising. Preliminary results encourage that permission be sought to enrich this corpus with all the theses in the Thesis Repository of the Union of Arab Universities. The JUPlag corpus is intended to function as an indispensable source for testing and evaluating plagiarism detection techniques. Since the University of Jordan is seeking to become a center for plagiarism detection for Arabic content and being a non-profit organization, it will charge a nominal fee for the use of JUPlag to finance the maintenance and development of the corpus.
\end{abstract}

Keywords: Corpus tools, Natural language processing, Plagiarism detection, Text plagiarism, Verbatim plagiarism

\section{Introduction}

Plagiarism is simply defined as appropriating others' words, thoughts, or intellectual property without providing proper citation or giving credit to them as the original source. The Oxford Dictionary ${ }^{1}$ defines plagiarism as "The practice of taking someone else's work or ideas and passing them off as one's own”. With the exceptionally large

\footnotetext{
${ }^{1}$ https://en.oxforddictionaries.com/definition/plagiarism
}

(c) The Author(s). 2020 Open Access This article is distributed under the terms of the Creative Commons Attribution 4.0 International License (http://creativecommons.org/licenses/by/4.0/), which permits unrestricted use, distribution, and reproduction in any medium, provided you give appropriate credit to the original author(s) and the source, provide a link to the Creative Commons license, and indicate if changes were made. 
volume of articles, reports and books available on the Internet, plagiarism in academic writing is a major concern that has become the matter of the moment.

Plagiarism can be either intentional or unintentional (DeVoss \& Rosati, 2002). It is intentional when copying or modifying someone else's words without providing proper citation to the original source. It is unintentional when one copies from others without knowing the rules and regulations for academic writing. However, ignorance should not be an excuse. For instance, the latest scandal of alleged plagiarism involved a respectable lecturer at an Ivy League university who once was the executive editor of a major newspaper. It cast doubt on the integrity and reputation of an otherwise highly respectable academic and public figure. This academic had properly credited alleged instances of plagiarism to their sources, sometimes repeatedly, but occasionally failed to do so. This 'unintentional plagiarism' is a form of academic dishonesty.

Advancement in technology both facilitates plagiarism and prevents it. At the click of a mouse, paper mill websites help students and researchers to copy or buy research papers. Yet, plagiarism detection systems deter the appropriation of others' intellectual property. Plenty of websites are nowadays offering tools for plagiarism detection. Some sites are commercial but few are free. Turnitin and PlagScan, for instances, are very popular commercial tools that are used world-wide for the detection of text plagiarism. They are capable of detecting different forms of plagiarism that range from simple copy-paste plagiarism to word switching, sentence and paragraph paraphrasing, etc. However, these tools do not prevent plagiarism but catch it after it has occurred (Beute, Van Aswegen, \& Winberg, 2008).

Misconduct in Arabic research is not an exception. Unfortunately, however, most of the plagiarism detection tools act on ASCII (American Standard Code for Information Interchange) data and very few support Unicode data for plagiarism comparisons. Plagiarism detection for scholarly research written in the Arabic language is not well supported. The scarcity of Arabic literature and resources on the Internet as well as the shortage of commitment to research in Arabic NLP (Natural Language Processing) are the main reasons behind the absence of efficient plagiarism tools that support a language spoken and written by around 423 million people.

The main contribution of this ongoing project is twofold. At its preliminary stage, it will construct a plagiarism corpus made of defended dissertations in the thesis repository at the library of the University of Jordan. The second is to develop a plagiarism detection system dedicated to the Arabic language that is capable of detecting verbatim plagiarism and some intelligent plagiarism including word order changes, paraphrasing and synonym replacement. Hereafter, we refer to the corpus as JUPlag and to the plagiarism detection system as PD system.

The remaining of the paper is organized as follows. Section 2 provides a background and discusses related literature. Section 3 introduces the research methodology. Section 4 discusses the experiments and findings. Finally, section 5 presents the conclusion of this paper and future work.

\section{Background and literature review Plagiarism}

The lack of fundamental research skills could be the common reason why university students/researchers plagiarize (Devlin \& Gray, 2007). However, academic 
writing is not an easy task. It requires clarity, conciseness, focus, structure, and evidence. It requires a lot of reading, appropriate usage of words and grammar, and learning how to express ideas and thoughts. Several studies pointed to other reasons for plagiarism: lack of author confidence, shortage of time, fear of failure, pressure of parents and scholarship committees to maintain high grades, lack of punishment by the institution, ease of appropriation, and absence of good plagiarism detection systems (Devlin \& Gray, 2007; Eret \& Ok, 2014; Franklin-Stokes \& Newstead, 1995).

From a legal point of view, the act of plagiarism is not considered a crime (Frye, 2016). However, plagiarism during university years is highly condemned by the academic community and it may leave a significant impact on one's career beyond academia. "Consequences range from loss of reputation to economic fines and ruined careers. Students are expelled from their schools, and faculty fired... Doctoral degrees can be revoked and plagiarizing publications are retracted and cursed" (Satija \& Martínez-Ávila, 2019, p. 90). A case in point is the disgrace of politicians (cf. Ruipérez \& García-Cabrero, 2016).

Plagiarism is of seven types: paraphrasing a text without proper citation, mosaic plagiarism where text from different sources is combined into one, copy and paste without due citation, incorrect citation, arrogating someone else's entire work, self-plagiarism where one submits his/her published work as though it were new, and citing a nonexisting work (Vij, Soni, \& Makhdumi, 2009).

Plagiarism prevention methods have a long-term positive effect, but, unfortunately, their implementation is usually time-consuming (Lukashenko, Graudina, \& Grundspenkis, 2007). Relying on such methods to maintain academic integrity, however, won't be enough to stop researchers from plagiarizing. In the words of Bolkan (2006), "Many educators blame the internet for what they perceive as the rise of plagiarism. Although the Internet certainly enables more efficient plagiarism, blaming it for widespread copying is akin to blaming a bank robbery on the presence of cash in the building ... Efforts must be directed at prevention as well as detection and punishment. (p. 4)".

Plagiarism detection software (PDS) can be content-based (extrinsic) or stylometrybased (intrinsic) (Rahman, 2015). Extrinsic plagiarism detection (EPD) discovers instances of appropriation by comparing a suspicious document with reference documents (a database or a corpus). Intrinsic plagiarism detection (IPD), on the other hand, discovers instances of appropriation in the suspicious document without using any reference corpus. Figure 1 depicts the common types of text plagiarism and the classification of plagiarism detection software tools.

A plagiarism detection system has to ideally handle most types of plagiarism, including text modification by word-shifting, translation, and summarization that bypass string-matching tools. At this preliminary stage, our present work handles stringmatching-based plagiarism detection and it is planned that it will be enhanced with such NLP techniques as stemming and part-of-speech tagging, and by the use of such lexical resources as the work of (Baras, Sawalha, and Yagi: A more extensive wordnet for Arabic, submitted), Arabic-WordNet, ${ }^{2}$ dictionaries, and thesauri.

$\overline{{ }^{2} \text { http://globalwordnet.org/arabic-wordnet/ }}$ 


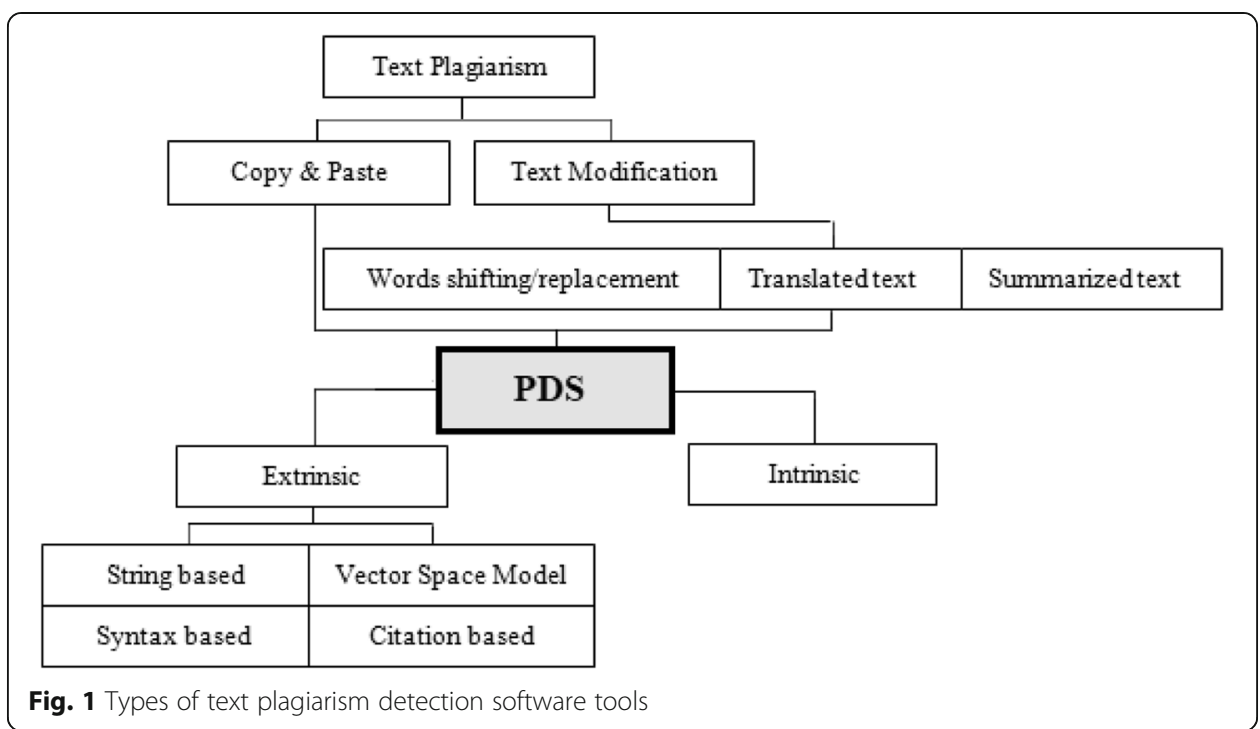

\section{Related work}

Plagiarism is an old topic and it has been well studied in the literature. In this section, we only focus on the recent work on Arabic text plagiarism detection. However, for further reading on the topic of plagiarism, we refer the reader to Maurer, Kappe, and Zaka (2006). In addition, the following is a sample of scholarly work that exemplifies plagiarism types with reference to Fig. 1. For intrinsic plagiarism, we refer the reader to the work of AlSallal, Iqbal, Palade, Amin, and Chang (2019), Polydouri, Siolas, and Stafylopatis (2017), Tschuggnall and Specht (2012), Zu Eissen and Stein (2006); for stringbased extrinsic plagiarism detection, refer to Baba, Nakatoh, and Minami (2017), Leonardo and Hansun (2017), Nakatoh, Baba, Yamada, and Ikeda (2011), Wise (1996); for vector-space-based plagiarism detection, see Kong, Zhao, Lu, Qi, and Zhao (2016), Meuschke, Siebeck, Schubotz, and Gipp (2017), Paul and Jamal (2015); for syntax-based plagiarism detection refer to Si, Leong, and Lau (1997), Vani and Gupta (2017); and for citation-based detection see Gipp and Beel (2010), Gipp and Meuschke (2011); and Meuschke, Gipp, Breitinger, and Berkeley (2012).

The first shared task that addressed plagiarism detection in Arabic texts is "AraPlagDet” (Arabic Plagiarism Detection) introduced in the PAN@Fire2015 competition and it has become since then an annual event that involved extrinsic and intrinsic plagiarism detection (Bensalem et al., 2015). Researchers in Arabic NLP adopted shared tasks to raise awareness of plagiarism problems and to develop solutions to them.

The majority of works on Arabic plagiarism detection involves preprocessing, segmenting documents into chunks of sentences of variable sizes (n-grams), tokenization, removing diacritics and non-alphanumeric characters, normalizing some letters (for ex-

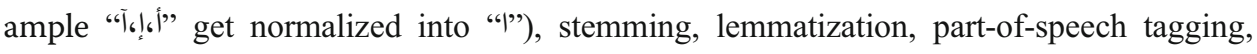
and synonym replacement.

Zaher, Shehab, Elhoseny, and Osman (2017) developed a web-based plagiarism detection system for Arabic documents, called APDS. The system operated in three phases: preparation, preprocessing, and similarity detection. After preprocessing, the query document was presented as n-gram chunks for similarity detection. The proposed system was tested on a dataset of 10 Arabic documents and evaluated in terms of 
precision and recall. The authors claimed an average precision of $82 \%$ and an average recall of (92.5\%). However, the paper does not tell what kind of plagiarism was detected, how the documents were presented or how the precision and recall measures were obtained.

Mahmoud and Zrigui (2017) proposed a system for detecting semantic plagiarism in Arabic documents that benefited from machine learning technology. In the preprocessing phase, the suspicious and source documents were split into sentences then into words without removing stopwords. In the feature extraction phase, the TF*IDF (Term Frequency-Inverse Document Frequency) measure was calculated for weighting words in terms of importance. Then the word2vec algorithm was used for learning word embeddings, and the skip-gram model was employed for predicting the context of words given a current word vector. For similarity calculation, they used cosine and the Euclidean distance measures. The degrees of similarity between sentences were compared to a predefined threshold. Experiments were conducted on an open source Arabic corpus and they claimed a precision rate of (85\%) and a recall rate of (84\%).

Mahmoud, Zrigui, and Zrigui (2017) used a Convolutional Neural Network (CNN) approach for detecting paraphrasing plagiarism in Arabic documents. This method is said to detect paraphrasing plagiarism through the measurement of semantic relatedness between the suspicious and the original documents. Their approach has three phases: preprocessing, feature extraction, and paraphrase detection. After preprocessing, the feature extraction phase employed a skip-gram model for word-to-vector representation, where each document is represented by a vector in a multidimensional space. The paraphrase detection phase applied the cosine similarity measure on the vectors of both the suspicious and the original documents to reduce dimensionality. Finally, a mathematical function called Softmax was used for paraphrase detection according to some predefined threshold. Experiments showed a precision rate of (88\%).

However, Mahmoud et al. (2017) and Mahmoud and Zrigui (2017) conducted their experimentation on an open source Arabic corpus, named OSAC (Saad \& Ashour, 2010). The corpus was organized in ten different categories collected from multiple websites. The sources of the articles were news channels and social and commercial websites, which clearly makes it inappropriate for academic plagiarism detection. Specialized content is what the PD corpus ought to consist of, because academics do not normally plagiarize the news or social media.

Abdelrahman, Khalid, and Osman (2017) presented a framework for content-based PD in Arabic documents. Their framework has two phases: preprocessing and document representation. They used a tree-structure model with the document at the root of the tree, the paragraphs at the second level, and the sentences at the third level of the tree. A Longest Common Substring (LCS) matching algorithm was used for comparing hashed text chunks (i.e. words in their case). No experiments were made to evaluate the system or show its effectiveness and therefore there was no plagiarism detection corpus.

Ghanem, Arafeh, Rosso, and Sánchez-Vega (2018) presented a system for detecting extrinsic plagiarism in Arabic texts. Their system, Hybrid Plagiarism (HYPLAG), followed a hybrid detection approach. They adopted corpus-based and knowledgebased approaches for the detection of both the verbatim and rephrasing types of plagiarism. The system was compared to other systems that participated in the Arabic 
Plagiarism Detection PAN-Forum for Information Retrieval Evaluation (AraPlagDet PAN@FIRE) competition and was tested on a corpus called External Arabic Plagiarism Detection (ExAraPlagDet-2015). The authors reported that HYPLAG outperformed others with a success rate of (89\%). They chunked the query (suspicious) document and the source documents into n-term sentences. Then the synonyms of the query document were extracted from the Arabic-WordNet. The original sentences were ranked with respect to the suspicious sentences and the ones with the highest scores were extracted as potentially plagiarized sentences. Finally, the candidate sentences and suspicious sentences were compared for similarity using the vector space model and the TF*IDF weighting measure. A similarity value that exceeded a predefined maximum threshold indicated plagiarism, while a similarity value between minimum and maximum thresholds required a call for the next phase of feature-based semantic similarity measurement based on the synonyms extracted from the Arabic-WordNet.

Khorsi, Cherroun, and Schwab (2018) used a Two-Level Plagiarism Detection System (2 L-APD), which is said to detect different plagiarism cases, including verbatim and paraphrasing. Their system consisted of two consecutive modules: fingerprinting and word embedding detection. The first module is responsible for preprocessing and segmenting the suspicious document into sentences. When sentences exceeded some threshold value, they were passed on to the second module to test for paraphrasing and synonym replacement. The fingerprinting was applied by chunking the text documents into n-grams and then selecting the least frequent ones. Finally, they used a function called Brian Kernighan and Dennis Ritchie (BKDR) for hashing the selected n-grams. The first module applied Jaccard measuring similarity, whilst the second module used the cosine similarity measure. Important words were picked on the basis of their IDF value and their part of speech tags. To test their approach, Khorsi et al. (2018) used the ExAraDet-2015 corpus. Experimental results showed an overall precision rate of (85\%) and a recall rate of $(87 \%)$.

Although the works of Ghanem et al. (2018) and Khorsi et al. (2018) seem promising, they both have been tested on ExAraDet-2015 corpus, which is an Arabic corpus made of short sentences constructed for the PAN@FIRE plagiarism detection competition. We suspect this corpus might not be suitable for academic plagiarism detection as it is not a well-organized academic corpus, neither it is discourse-structure annotated.

Clearly, there is need for a corpus dedicated to plagiarism detection that is authentic, big, versatile, and richly annotated. The JUPlag corpus is intended to meet this need and to function as a test bed for the evaluation of plagiarism detection techniques.

\section{Corpus design methodology}

The JUPlag corpus was guided by the following design objectives:

1) To compile academic texts for the purpose of training and testing the Arabic plagiarism detection system that is to be developed.

2) To devise a mechanism for organizing the texts and indexing them.

3) To annotate the texts using a stemmer and a part-of-speech tagger.

4) To construct an Arabic thesaurus database that can be used for detecting synonym replacements. 


\section{Source data collection}

Data collection is a fundamental success factor in plagiarism detection. PD systems need to access multitudes of sources of data to detect potential plagiarism. This includes accessing local databases as well as online data available on the internet. Due to the scarcity of scholarly Arabic literature that is in digitized form, it has been deemed necessary to build a resource that would contain a collection of academic texts, a resource that may be used for the detection of plagiarism in dissertations before a defense is scheduled. Postgraduate students usually sign an affidavit stating that they observed the code of ethics in the compilation of their theses, that they accepted all legal repercussions of plagiarism including the revocation of their degrees, and that they agreed that the Deans Council revocation decision would be final.

With the necessary legal provisions, the Library of the University of Jordan graciously gave us permission to access their copyrighted repository of dissertations. The University requires that postgraduate students transfer their copyrights to it and get them to sign an authorization form that permits the University of Jordan "to supply copies of [their] Thesis/Dissertation to libraries or establishments or individuals on request, according to the University of Jordan regulations". We have obtained permission of the University administration and of the Director of the University Library to access the dissertation repository for the specific purpose of the development of the JUPlag corpus and for experimentation with the repository.

We had access to (2312) dissertations that were defended by University of Jordan postgraduate students between the years 2001-2016. Table 1 shows the number of collected dissertations per year. Notice the significant increase in the number of collected dissertations in 2006 and beyond; this is due to the School of Graduate Studies' drive to boost the number of master's, doctoral and high specialization programs. As JU sought to become a pioneer in postgraduate programs, it widened its program offerings resulting in 2012 in (105) master's programs, (34) doctoral programs, and (16) high specialization programs in Medicine. As of today, the Graduate School offers (123) master's programs, (38) doctoral programs, (16) high specialization programs in Medicine, and (1) high specialization program in Dentistry.

\section{Challenges identified}

In the process of constructing the JUPlag corpus, the following problems were encountered:

Table 1 Per year distribution of the collected dissertations

\begin{tabular}{llll}
\hline Year & Count & Year & Count \\
\hline 2001 & 23 & 2009 & 203 \\
2002 & 7 & 2010 & 261 \\
2003 & 13 & 2011 & 174 \\
2004 & 18 & 2012 & 141 \\
2005 & 47 & 2013 & 187 \\
2006 & 126 & 2014 & 317 \\
2007 & 202 & 2015 & 282 \\
2008 & 186 & 2016 & 125 \\
Total $=2312$ & & & \\
\hline
\end{tabular}




\section{1) Differences in dissertation format and structure}

Although the school of graduate studies at JU has guidelines and a standardized template for dissertations, there are some variations among schools and disciplines. This might include the number of chapters, pages, dissertation layout, and fonts. For the past 10 years, a graduate student has been required by law to hand in an electronic copy of his/her dissertation upon its endorsement by the school of graduate studies. Prior to that, hard copies were submitted to the library whose staff had to retype the dissertations, a cumbersome and costly exercise.

Due to copyright law restrictions, we had to obtain permission to process the content of the repository for the purpose of constructing the JUPlag corpus.

\section{2) Scarcity of Arabic online literature}

The success of plagiarism detection is dependent mainly on access to online resources and on offline databases. Unfortunately, there is a limited volume of machinereadable Arabic scholarly articles online. Hence, testing our system will be restricted to JUPlag corpus. At a later stage, we will seek permission to include in this corpus all the dissertations in the repository of the Union of Arab Universities.

\section{3) Paucity of efficient Arabic tools}

Arabic suffers from the scarcity of free NLP tools. Tokenization, root extraction, part of speech tagging, and sentence boundary identification are essential for many NLP tasks. Root extraction reduces word tokens to word types. A Part-of-Speech Tagger (POST) is essential for machine translation, dependency parsing, and language pattern extraction. Online dictionaries, thesauri, and semantic networks are indispensable for meaning-centered tasks. Although many of these essential tools do exist, they are not available for free. Many of those that are free of charge are not reliable. Hence, researchers in the field of Arabic NLP often decide to build their own tools.

\section{Construction of the Arabic academic plagiarism detection corpus}

To the best of our knowledge, the only available extrinsic plagiarism corpus devoted to Arabic text plagiarism detection is ExAraDet-2015. ${ }^{3}$ The corpus was used in the PAN@Fire2015 competition to judge and to rank the competing solutions. The corpus is made of 1171 short documents, of which (48.68\%) are source documents and (51.32\%) are suspicious. The following is a detailed description of our design and construction of JUPlag, the Arabic academic plagiarism detection corpus.

\section{Corpus architecture}

The architecture of JUPlag follows the Library of JU in the way it classifies its content. JU Library holdings are classified in accordance with the DDC system and it uses some standard metadata. The following is a brief description of the two classification techniques that we adopted while building the plagiarism corpus.

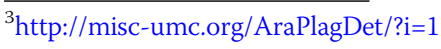


The Dewey decimal classification system

The DDC ${ }^{4}$ system is the world's most widely used technique to organize library collections. It has been named after its founder, Melvil Dewey, an American Librarian who developed it in 1876. The DDC system represents an adaptive knowledgebase which is revised continuously to cope up with knowledge development. It has been developed and maintained by the Library of Congress. The DDC system has 10 main subject categories. Each category is represented by a three-figure value in the range from 000 to 999 (Chan, Comaroni, Mitchell, \& Satija, 1996).

The JU Library had adopted DDC in the classification of its holdings, whether they are books, magazines, periodicals, or dissertations, etc. As Fister (2009) notes, "Dewey can sort large collections into more specific groups than BISAC can. (p. 24)".

A Dewey numerical scheme has three levels. Altogether, they make the classification number of a library item. Table 2 shows the first level categories. For instance, a dissertation about Arabic dictionaries "المعاجم العربية" would carry the Dewey number 413. The number can be interpreted as follows. Level-1 (400) is used for the language "اللغاتحرب "cat"اللغة العربية" " category, and the third level (3), a sequential number, is used for the Arabic Dictionary "المعاجم العربية" category.

\section{JU library's metadata}

In addition to using DDC for classifying its items, the JU Library also adopts a set of standard metadata for their classification. The metadata include: barcode, author's first name, author's surname, title, date of publication, subject, and the call number that specifies the shelf location of the item. Metadata are used to locate and retrieve information quickly.

An interesting characteristic of JUPlag is that its content is organized according to DDC system. This organizational structure is advantageous in that it categorizes theses/dissertations according to subject matter which makes it possible to perform plagiarism detection within a subcorpus rather than the entire corpus, a procedure that saves precious processing power and time. Search in one DDC category of theses/

Table 2 Dewey decimal classification system

\begin{tabular}{|c|c|c|}
\hline Dewey \# & English Categories & JU Arabic Categories \\
\hline 000-099 & General References or Works & المعارف العامة (العموميات) \\
\hline 100-199 & Philosophy, psychology \& logic & الفلسفة وعلم النفس و المنطق \\
\hline 200-299 & Religion & 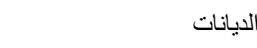 \\
\hline 300-399 & Social Sciences & العلوم الاجتماعية العية \\
\hline $400-499$ & Language & اللغات \\
\hline $500-599$ & Natural Science & العلوم الطبيعية \\
\hline $600-699$ & Technology and Applied Science & العلوم التطبيقية (التكنولوجيا) \\
\hline 700-799 & Fine Arts \& Recreation & الفنون الجميلة \\
\hline $800-899$ & Literature & 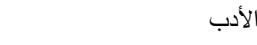 \\
\hline 900-999 & History, Geography \& Biography & التاريخ و الجغر افيا و السير \\
\hline
\end{tabular}

$\overline{{ }^{4} \text { https://www.oclc.org/en/dewey/features/summaries.html }}$ 
dissertations is also what linguistic analysis would do when they want to study the discourse characteristics of a genre or its embedded linguistic patterns.

In a similar manner, DDC has been successfully used by Jenkins, Jackson, Burden, and Wallis (1998) to automatically classify web resources and by Golub, Lykke, and Tudhope (2014) to enhance Information Retrieval (IR) and indexing systems.

\section{Data processing outline of the JUPlag corpus}

In this section, we describe the processing stages of the corpus construction. Figure 2 depicts the overall data processing stages. Table 3 shows the distribution of the corpus dissertations in accordance with the Dewey categories.

\section{Tokenization}

The tokenization process takes a dissertation $D$ and splits it into separate words (unigrams). We designed and implemented a tokenizer that extracts words at multiple delimiters, including white spaces, tabs and punctuation marks (Hammo, Yagi, Ismail, \& AbuShariah, 2016). The output of the tokenizer is of two types: tokens that correspond to units whose characters are recognizable such as punctuation marks, numeric data, dates, etc., and tokens that need further morphological analysis. Tokens of one or twocharacter length, non-Arabic characters, or numerical values are ignored and excluded from the database. Stop-words were also removed from the corpus. Developers of NLP applications usually remove stop-words from search engine indices as this will reduce

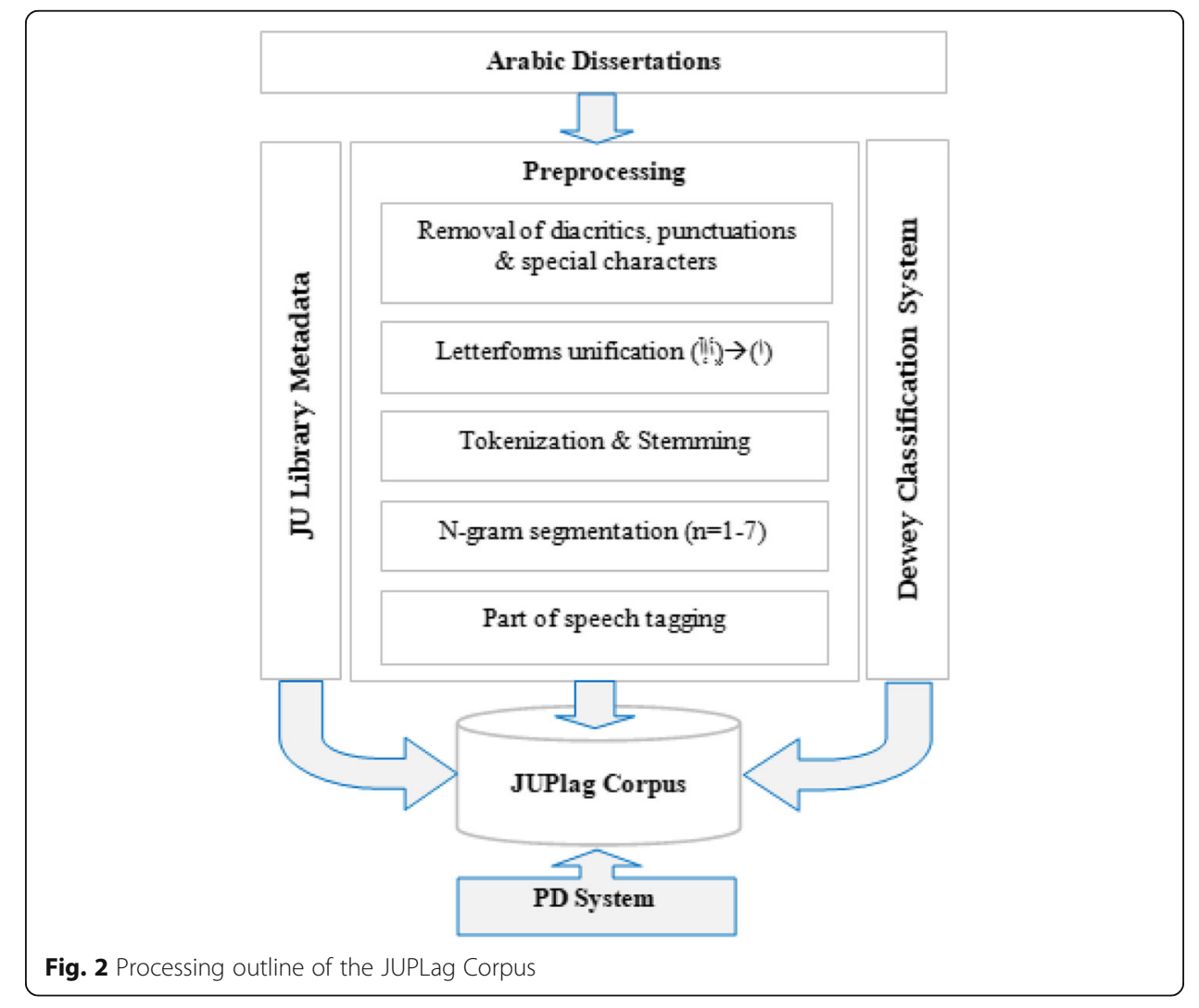


Table 3 Distribution of the corpus dissertations in accordance with Dewey's categories

\begin{tabular}{|c|c|c|c|}
\hline Dewey \# & English Categories & JU Arabic Categories & Number of Dissertations \\
\hline 000-099 & General References or Works & المعارف العامة (العموميات) & 17 \\
\hline 100-199 & Philosophy, psychology \& logic & الفلسفة وعلم النفس و المنطق & 10 \\
\hline 200-299 & Religion & 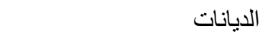 & 397 \\
\hline 300-399 & Social Sciences & العلوم الاجتماعية & 1338 \\
\hline 400-499 & Language & اللغات & 42 \\
\hline 500-599 & Natural Science & العلوم الطبيعية & 17 \\
\hline 600-699 & Technology and Applied Science & العلوم التطبيقية (التكنولوجيا) & 103 \\
\hline 700-799 & Fine Arts \& Recreation & الفنون الجميلة والديكور & 147 \\
\hline 800-899 & Literature & 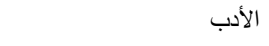 & 134 \\
\hline 900-999 & History, Geography \& Biography & التاريخ و الجغر افيا و السير & 107 \\
\hline Total & & & 2312 \\
\hline
\end{tabular}

the size of indices dramatically (Salton \& Buckley, 1988; Yang, 1995) and that will improve recall and precision.

\section{Segmenting dissertations into n-grams}

For a given dissertation $D$, we split the sentences of $D$ into n-gram segments. An ngram segment is a substring of $n$ consecutive words. The popular forms of $n$-grams include bi-gram ( 2 words), tri-gram ( 3 words), and four-gram ( 4 words). The maximum value we considered in preparing the corpus is $n=7$ (seven-gram). The $n$-grams will be used later in a string matching algorithm to detect similarity between the source sentences and the suspicious ones.

Before the splitting process, punctuation, special characters, and diacritics get removed and letterforms normalized; i.e., all shapes of alif and hamza get converted to one form each. To explain how the n-gram segments were formed, consider the Arabic sentence "ذهب احمد الى السوق واثترى خبزا و عسلا" and its English translation, "Ahmad went to the market and bought bread and honey". A sliding window of size $n$ splits this text as demonstrated in Table 4.

\section{Stemming}

Stemming is the process of mapping derivative words onto the base form, the stem, that they share. Stemming uses morphological heuristics to remove affixes from words

Table $4 \mathrm{~N}$-gram segments generated from a sentence

\begin{tabular}{|c|c|c|c|}
\hline Unigram & Bigram & Trigram & $4-g$ \\
\hline ذهب & ذهب احمد & ذهب احمد الى & ذهب احمد الى السوق \\
\hline احمد & احمد الى & احمد الى السوق & احمد الى السوق واشترى \\
\hline 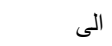 & الى السوق السوق & الى السوق و اشترى & الى السوق و اشترى خبزا \\
\hline 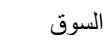 & السوق و اثشترى & السوق و اشترى خبزا & السوق واشترى خبز ا وعسلا \\
\hline و واشترى & و واثترى خبزا & و انشترى خبز ا وعسلا & \\
\hline خبزا & خبزاو عسلا & & \\
\hline و عسلا & & & \\
\hline
\end{tabular}


before indexing them. Arabic stemming is more complex than it is in English. Arabic is a morphologically introflexive, fusional language (Velupillai, 2012), whilst English is morphologically hybrid. Sapir and Swiggers (2008) label English as a mixed-relational fusional language. The majority of words in the Arabic language, on the other hand, are primarily constructed from three-consonant roots and a set of morphological patterns. With prefixes, infixes, and/or suffixes interdigitated with the root radicals, multitudes of words are derived. Then these coined words, if generated with verb patterns, get inflicted for number, gender, mood, voice, and tense; if generated with noun patterns, they get inflicted for number, definiteness, and case. An Arabic stemmer should identify the base word and remove all inflectional and derivational affixes. It should recognize, for example, that the strings, كاتب kAtib 'writer', كتاب kitAb 'book', ككتبة maktabatun 'library', as belonging to one root, كتب KTB 'to write'. For this task, we used Khoja and Garside's (1999) Arabic stemmer.

\section{Part of speech tagging (POST)}

A part-of-speech tagger (POST) is a software application that reads text in a particular language and assigns to each word its word category; i.e., it marks it as noun, verb, adjective, etc. Part of speech tagging is an essential process in understanding how sentences are formed from small constituents. It is mainly used in syntactic and semantic analysis of sentences. For this task, we used MADAMIRA, ${ }^{5}$ a comprehensive tool for Morphological Analysis and Disambiguation of Arabic. Adding POS annotations to the corpus is mainly to prepare the corpus for the next stage of this ongoing project. Similar to the work of Elhadi and Al-Tobi (2008), we intend to use the part-of-speech tags to represent the structure of text segments for further comparisons and analysis. Plagiarized text tends to have the same POS tag features as the original source.

\section{The final academic corpus}

The final academic corpus (database) constitutes the core of the Arabic plagiarism detection system, with its n-gram segmentation and metadata annotation, and morphological annotation of each word in the collection. The corpus is accessed through our plagiarism detection system as we will explain in Section 4. Preprocessing, as explained in Fig. 2, includes removal of diacritics, punctuation and special characters. Letterform unification (i.e. "ढإढ" are normalized to "l"), n-gram segmentation ( $n=1-7)$, part-of-speech tagging, stemming, and tokenization are also performed at this stage. Table 5 shows the final distribution of the collected texts (i.e., 2312 dissertations) as per the Dewey categories. The corpus statistics will be outlined subsequently.

\section{Experiments and discussion}

\section{Experimenting with the JUPlag corpus: analysis and statistics}

As stated earlier, the goal of constructing the JUPlag corpus is twofold. First, it is intended to be used to detect plagiarism in students' assignments, reports, and new dissertations prior to submission for defense. Secondly, its unique design structure

\footnotetext{
$\overline{{ }^{5} \text { https://camel.abudhabi.nyu.edu/madamira/ }}$
} 
Table 5 Detailed classification of the corpus texts based on Dewey's categories

\begin{tabular}{|c|c|c|c|}
\hline $\begin{array}{l}\text { Dewey } \\
\text { (Level-2) }\end{array}$ & Arabic Categories & English Categories & $\begin{array}{l}\text { Number of } \\
\text { Dissertations }\end{array}$ \\
\hline 004 & معالجة البيانات, علم الحاسوب & Data processing \& computer science & 17 \\
\hline 020 & علم المكتبات و المعلومات & Library \& information sciences & \\
\hline 150 & 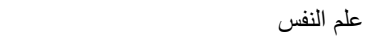 & Psychology & 10 \\
\hline 210 & الإسلام و علومه & Philosophy \& theory of religion & 397 \\
\hline 220 & القرآن الكريح و علومه & Holy Quran and its Sciences & \\
\hline 290 & 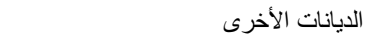 & Other religions & \\
\hline 301 & علم الاجتماع و الانثروبولوجيا & Sociology \& anthropology & 1338 \\
\hline 302 & التفاعل الاجتماعي & Social interaction & \\
\hline 303 & 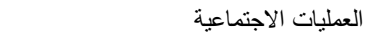 & Social processes & \\
\hline 304 & العو امل المؤثرة في السلوك الاجتماعي & Factors affecting social behavior & \\
\hline 305 & 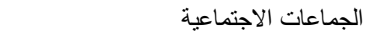 & Groups of people & \\
\hline 306 & الثقافة ومؤسساتها & Culture \& institutions & \\
\hline 307 & المجتمات & Communities & \\
\hline 320 & 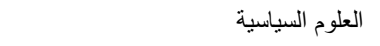 & Political science (Politics \& government) & \\
\hline 330 & الاقتصاد & Economics & \\
\hline 340 & 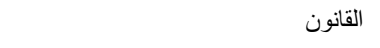 & Law & \\
\hline 350 & 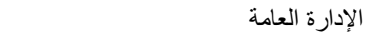 & Public administration \& military science & \\
\hline 360 & الخدمات الاجتماعية؛ الجمعيات & Social problems \& services; associations & \\
\hline 370 & التربية و التعليم & Manners \& education & \\
\hline 380 & التجارة , الاتصالات, النقل & Commerce, communications, transportation & \\
\hline 401 & اللغويات, علم اللغة & Philosophy \& theory; international languages & 42 \\
\hline 410 & اللغة العربية & Linguistics & \\
\hline 507 & التعليم والموضو عات ذات الصلة & Education, research, related topics & 17 \\
\hline 510 & 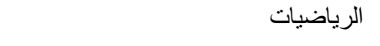 & Mathematics & \\
\hline 530 & الفيزياء & Physics & \\
\hline 540 & الكيمباء و العلوم ذات الصلة & Chemistry \& allied sciences & \\
\hline 550 & علوم الأرض (الجيولوجيا) & Earth sciences & \\
\hline 570 & علوم الحياة (علم الأحباء) & Biology & \\
\hline 580 & علوم النبات & Plants & \\
\hline 610 & العلوم الطبية (الطب) & Medicine \& health & 103 \\
\hline 630 & 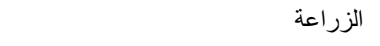 & Agriculture \& related technologies & \\
\hline 650 & إدارة الأعمال و الخدمات المساعدة & Management \& auxiliary services & \\
\hline 710 & تخطيط المدن و العمران & Area planning \& landscape architecture & 147 \\
\hline 720 & الهندسة المعمارية (العمارة) & Architecture & \\
\hline 780 & 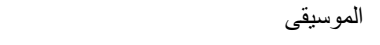 & Music & \\
\hline 790 & الفنون الترفيهية و الاستعر اضية & Recreational \& performing arts & \\
\hline 808 & البلاغة الأدبية ومجمو عات الأدب & Rhetoric \& collections of literary texts & 134 \\
\hline 809 & تاريخ ونقد الأدب & History, description \& critical appraisal & \\
\hline 810 & 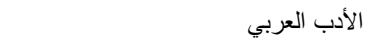 & Arabic literature & \\
\hline 907 & التعليم والبحث و الموضوعات ذات الصلة & Education, research, related topics of history & 107 \\
\hline 910 & 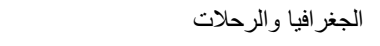 & Geography \& travel & \\
\hline 930 & تاريخ العالم القديم & History of ancient world to ca. 499 & \\
\hline 940 & ت ت ت اريخ أوروبا العام & History of Europe & \\
\hline
\end{tabular}


Table 5 Detailed classification of the corpus texts based on Dewey's categories (Continued)

\begin{tabular}{lllc}
\hline $\begin{array}{l}\text { Dewey } \\
\text { (Level-2) }\end{array}$ & Arabic Categories & English Categories & $\begin{array}{c}\text { Number of } \\
\text { Dissertations }\end{array}$ \\
\hline 950 & History of Asia & \\
Total & & & 2312 \\
\hline
\end{tabular}

provides a knowledgebase for linguistic analysis, language teaching, and the learning of plagiarism-free writing. In this respect, the user can query a subset of the corpus to retrieve language patterns that are favored in the particular discipline to which this subcorpus is dedicated. For example, frequency word lists can be generated for a particular discipline; thus, technical lexicography can be facilitated. The corpus can also be used to demonstrate plagiarism-avoidance strategies in research methodology courses and to teach linguistic patterns in writing and linguistic analysis courses.

To experiment with this corpus, a linguistic concordancer described in Hammo et al. (2016) is used to inquire about words and n-gram sentences in the database. Metadata such as subject topic, author name, and publication date are used to facilitate search and filter retrieved data.

\section{Word statistics}

The JUPlag academic corpus has around 60 million words and $(825,363)$ word types. Table 6 shows the top 20 words in the corpus, their English translation and their frequencies.

It is interesting to observe that the most frequent words in this predominantly social science corpus are general academic words and none of them is discipline-specific. Probably, the only words that betray the nature of the texts in this corpus are the words for 'God', 'Mohammad', and 'Jordan' since the theses/dissertations were produced in a Muslim country, Jordan.

It is also interesting to have an insight into the content of the corpus from a statistical perspective. In this context, "information theory states that messages maximize their capacity to convey information when the content follows Zipf's law". For a text corpus, Zipf's law specifies that, given a large sample of words, if $w_{1}$ is the most common word in the corpus, $w_{2}$ is the next most common, then the frequency of the $i^{\text {th }}$

Table 6 Top 20 frequent words in the corpus and their English translation

\begin{tabular}{|c|c|c|c|c|c|c|c|}
\hline Rank & Arabic Word & English Meaning & Frequency & Rank & Arabic Word & English Meaning & Frequency \\
\hline 1 & الدر اسه & The study & 260,127 & 11 & دراسه & Study & 76,374 \\
\hline 2 & 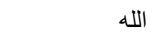 & Allah (God) & 222,662 & 12 & وجود & Existence & 75,484 \\
\hline 3 & الطلبه & Students & 103,332 & 13 & رقم & Figure & 75,422 \\
\hline 4 & محمد & Mohammad & 94,735 & 14 & استخدام & Use & 69,369 \\
\hline 5 & العطل & Work & 94,469 & 15 & يمكن & Possible & 68,652 \\
\hline 6 & الأول & First & 94,151 & 16 & عام ام & Year & 67,907 \\
\hline 7 & العربيه & Arabic & 93,333 & 17 & عدم & Un/Not & 66,971 \\
\hline 8 & الثناني & Second & 87,322 & 18 & الأردن & Jordan & 66,684 \\
\hline 9 & مستوى & Level & 81,435 & 19 & نتائج & Results & 66,390 \\
\hline 10 & دار & House & 76,968 & 20 & بشكل & Form & 65,314 \\
\hline
\end{tabular}




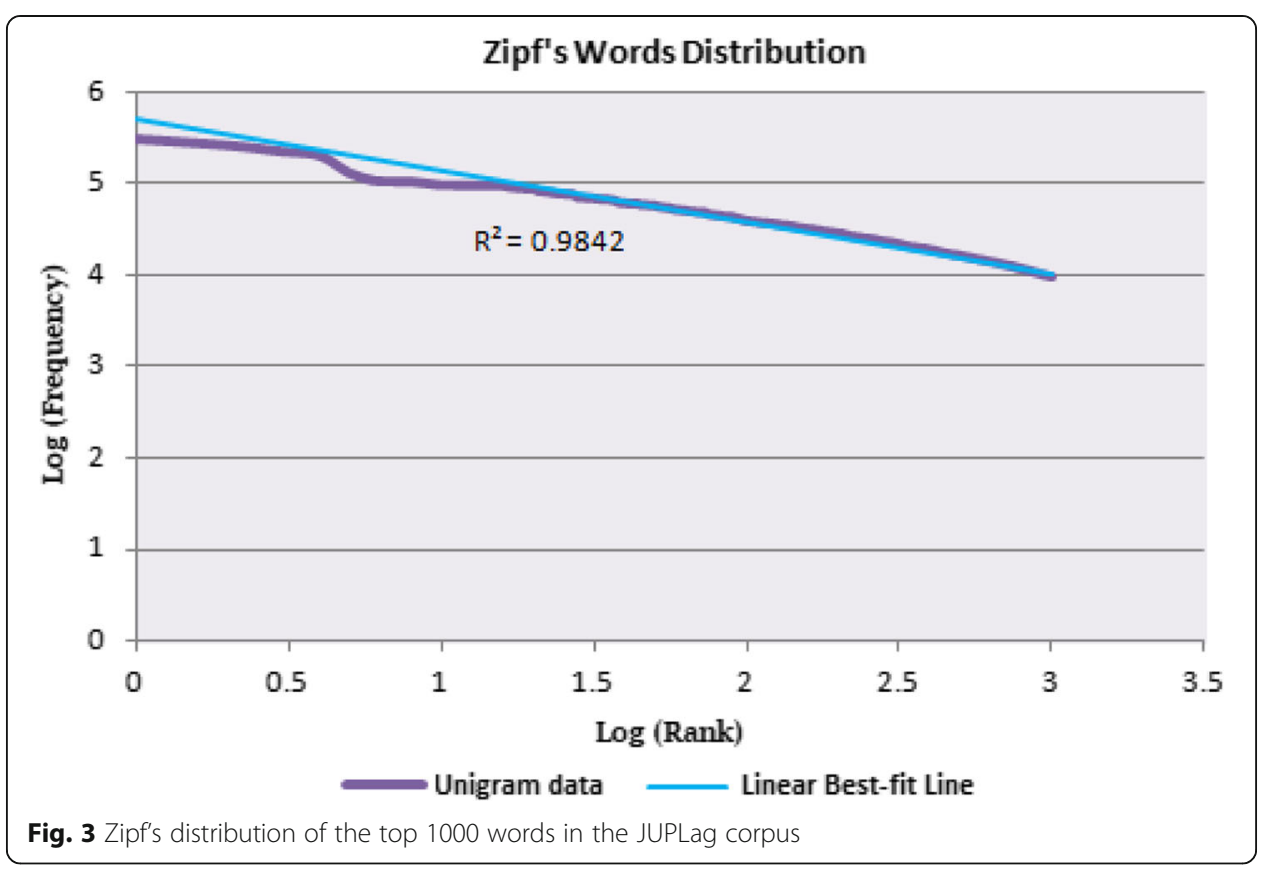

most common word is inversely proportional to its rank in the frequency table. So word number $i$ has a frequency proportional to $1 / i$.

To visualize how words are distributed across the corpus, we used a log-log scatter chart which plots the collection's frequency of a word as a function of its rank for the top 1000 words in the JUPlag corpus as shown in Fig. 3. The linear trendline shown along the curve in the chart is a best-fit straight line that is used with simple linear datasets to determine if the data follows Zipf's law. It is most reliable when the calculated $R$-squared $\left(R^{2}\right)$ value of the best-fit line is equal or close to 1 . For the unigram

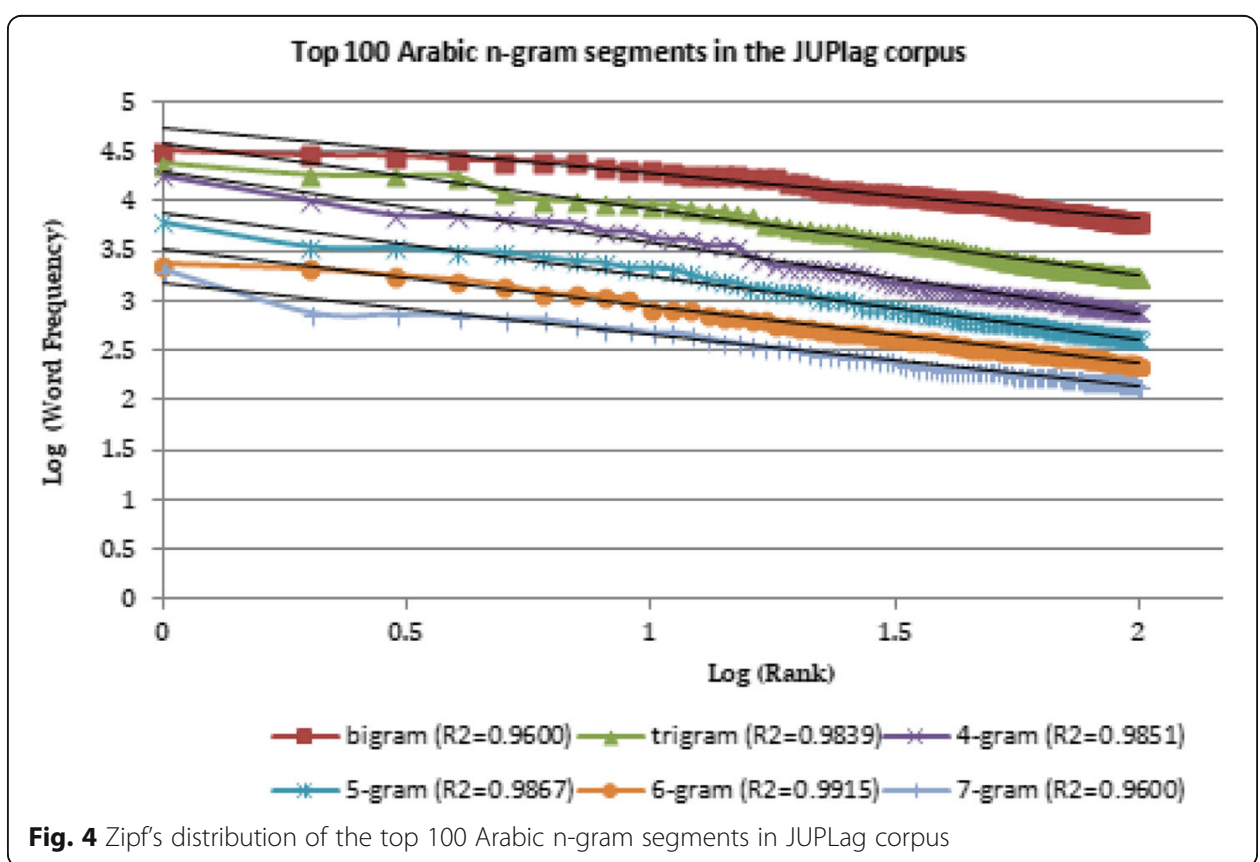


sample, the $R^{2}$ value was $(0.9842)$, which indicates that the unigram distribution is around the Zipf's law distribution.

\section{Sentence statistics}

According to Coxhead (2000), Zipf's law has been used often by language educators to identify the most common words/sentences for purposes of teaching foreign languages. Figure 4 shows the log-log scatter chart plot of the top 100 n-gram segments; it depicts how distribution of the top 100 n-gram chunks in JUPlag observes Zipf's law. Figure 4 also shows that the $\mathrm{R}^{2}$ values for all trendlines corresponding to the $\mathrm{n}$-gram segments are very close to 1 , which again indicates excellent fit of the n-gram segments to Zipf's law distribution.

Now let's take a look at the top $10 \mathrm{n}$-gram segments sampled from the JUPlag corpus as shown in Table 7.

From Table 7, it is interesting to observe that the most frequent n-gram segments in this predominantly social science corpus are statistical expressions. Examples of bigrams are "عينة الدراسة" (study sample) and "المنوسطات الحسابية" (statistical means). An

Table 7 Top 10 frequent n-gram segments in the JUPlag corpus

\begin{tabular}{|c|c|c|c|c|c|c|}
\hline Rank & $N=2$ & $N=3$ & $N=4$ & $N=5$ & $N=6$ & $N=7$ \\
\hline \multirow[t]{2}{*}{1} & 33,453 & 24,438 & 18,120 & 6203 & 2378 & 2078 \\
\hline & الدر اسية & صلى الله وسلم & والانحر افات المعيارية الحسابية & رسول الله صلى الله وسلح & رسالة ماجستير منشورة & رسالة ماجستير منشورة الجامعة \\
\hline \multirow[t]{2}{*}{2} & 29,861 & 18,789 & 10,226 & 3520 & 2117 & 763 \\
\hline & المتوسطات & و الانحر افات المعيارية & وجود فروق دلالة & عدم وجود فروق دلالة & ماجستير منشورة الجامعة & منشورة جامعة عمان العربية \\
\hline \multirow[t]{2}{*}{3} & 29,468 & 18,330 & 7266 & 3410 & 1838 & 731 \\
\hline & الحصائية & $\begin{array}{l}\text { والمتوسطات } \\
\text { والانحر افابية }\end{array}$ & النبي صلى الله وسلم & فروق دلالة احصائية & $\begin{array}{l}\text { تم حسابية المتوسطات الانحر افات } \\
\text { المعيارية }\end{array}$ & جامعة عمان العربية للار اسات العارن \\
\hline \multirow[t]{2}{*}{4} & 26,967 & 18,086 & 6979 & 3135 & 1660 & 717 \\
\hline & صلى الله & فروق دلالة & رسول الله صلى الله & منشورة الجامعة الأردنية & وجود فروق دلالة احصائية & وجود فروق دلالة احصائية \\
\hline \multirow[t]{2}{*}{5} & 26,167 & 11,953 & 6563 & 3092 & 1469 & 660 \\
\hline & محمد بن & وجود فروق & الله صلى الله وسلم & وجود فروق دلائة مستوى & $\begin{array}{l}\text { فروق دلالة احصائية مستوى الدلالة الفا } \\
\text { الدائل }\end{array}$ & فروق دلالة احصائية مستوى الدلائل الفا \\
\hline \multirow[t]{2}{*}{6} & 25,698 & 10,390 & 6262 & 2733 & 1224 & 658 \\
\hline & الله وسلم ل & المملكة العربية & فروق دلالة احصائية & رسالة ماجستير منشورة & 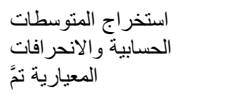 & عدم وجود فروق دلالة احصائية \\
\hline \multirow[t]{2}{*}{7} & 25,373 & 10,127 & 6023 & 2528 & 1179 & 590 \\
\hline & عبد الله & دل ملالة احصنئية & دار الكتب العلمية & $\begin{array}{l}\text { الحسابية والانحر المنات المبات } \\
\text { المبيارية }\end{array}$ & توجد فروق دلالة احصائية & هل ثوجد فروق دلالة احصائية \\
\hline \multirow[t]{2}{*}{8} & 22,130 & 9707 & 5001 & 2419 & 1128 & 535 \\
\hline & المستبط & الفر الد اسينة & دلالة احصائية مستوى الدلالة & ماجستير منشورة الجامعة & عدم وجود فروق دلالة & توجد فروق دلالة احصائية \\
\hline \multirow[t]{2}{*}{9} & 21,992 & 9463 & 4979 & 2145 & 1060 & 518 \\
\hline & الدائج & وزارة التربية & منشورة جامعة ماجتير & دلالة احصائية مسنوى الدلالة الفا & هل نوجد فروق دلالة & رسالة ماجستير منشورة جامعة اليرمو الربد \\
\hline \multirow[t]{2}{*}{10} & 21,133 & 9325 & 4320 & 2131 & 842 & 482 \\
\hline & فروق دلالة & رسالة ماجنتير & توجد فروق دلالة & توجد فروق دلالة احصائية & منشورة جامعة عمان العربية & المتوسطاتية لاستجابيات والانحر افنات \\
\hline
\end{tabular}




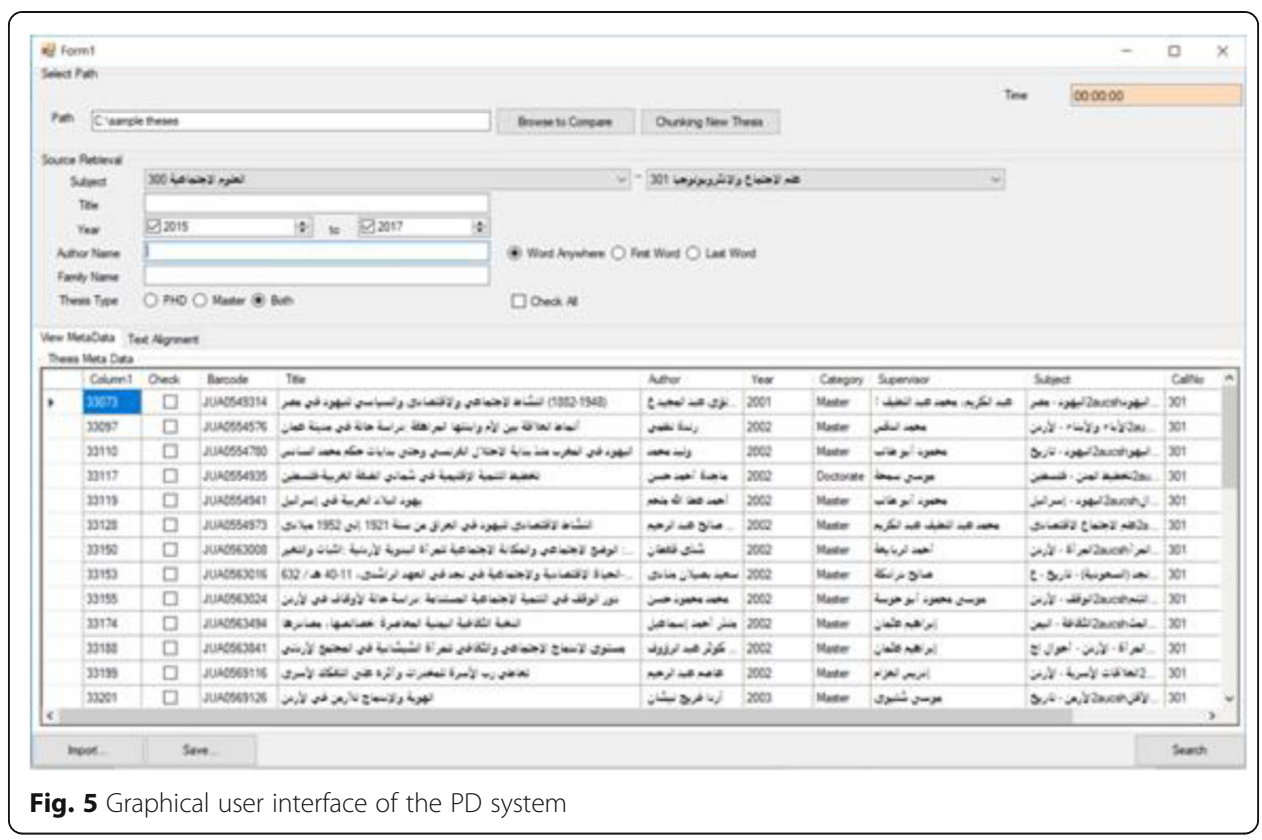

example of a trigram segment is "الحسابية والانحر افات المعيارية" (statistical and standard deviations), 4-g to 7-g samples are: "الكنوسطات الحسابية والانحر افات المعيارية" (statistical means and standard deviations), "عدم وجود فروقات دلالة احصائية" (there are no statistically significant differences), “"تم حساب المتوسطات الحسابية والانحر افات المعيارية" (statistical means and standard devi-

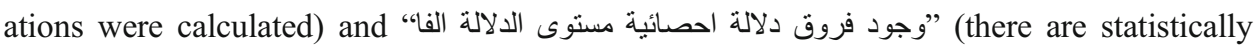
significant differences level alpha) respectively.

Observation also indicates that most of the dissertations in the social sciences in this corpus appear to require surveys, collecting and analyzing data, and calculating statistics. Hence, the JUPlag corpus can be used as a knowledge base for the teaching of empirical research.

\section{Experimenting with the plagiarism detection system}

To experiment with the academic plagiarism corpus, we implemented a plagiarism detection (PD) system as shown in Fig. 5. The PD system is guided by the DDC system and the JU Library's metadata for retrieval and discovery of plagiarism. A new submitted dissertation can be checked for plagiarism either in a specific Dewey category

Table 8 Characteristics of the test dataset

\begin{tabular}{|c|c|c|c|c|c|c|}
\hline \multirow[t]{2}{*}{ Segment } & \multicolumn{2}{|c|}{$\begin{array}{l}\text { Untampered Test } \\
\text { Dataset }\end{array}$} & \multicolumn{2}{|c|}{$\begin{array}{l}\text { Test Dataset with Plagiarized } \\
\text { Paragraphs }\end{array}$} & \multicolumn{2}{|c|}{$\begin{array}{l}\text { Test Dataset with Plagiarized } \\
\text { Sentences }\end{array}$} \\
\hline & Count & unique count & Count & unique count & count & Unique count \\
\hline unigram & 632 & 413 & 735 & 487 & 678 & 441 \\
\hline bigram & 631 & 586 & 734 & 682 & 677 & 626 \\
\hline trigram & 630 & 618 & 733 & 718 & 676 & 662 \\
\hline $4-g$ & 629 & 624 & 732 & 725 & 675 & 672 \\
\hline $5-g$ & 628 & 627 & 732 & 730 & 674 & 673 \\
\hline $6-g$ & 627 & 627 & 731 & 731 & 673 & 673 \\
\hline $7-g$ & 626 & 626 & 729 & 729 & 672 & 672 \\
\hline
\end{tabular}


Table 9 Samples of unique bigrams labeled as plagiarized

\begin{tabular}{|c|c|c|c|}
\hline Title of Source Dissertation & Plagiarized Bigrams & English Translation & Frequency \\
\hline \multirow{4}{*}{ عمل الزوجة وأثره على أوضاعها الأسرية: دراسة ميدانية على عينة في مدينة مسقط } & الاجتماعية والاقتصادية & Social \& economical & 15 \\
\hline & 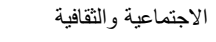 & Social \& cultural & 7 \\
\hline & اوضحت نتائج & Results showed & 2 \\
\hline & الاجتماعية والاقتصادية & Social \& economical & 9 \\
\hline
\end{tabular}

(subcorpus) or it can be checked against the entire JUPlag corpus. Our experimentation here utilizes both types.

To test the PD system, we obtained a new dissertation from the School of Graduate Studies at JU. The dissertation was in the field of "Sociology" "علم الاجتماع" which by Dewey's classification belongs to the superordinate class of "Sociology and Anthropology” " subclass. At this early stage in our project, we only focused on copy-\&-paste phenomena, verbatim plagiarism. The test dataset consists of three pages that were extracted from this new dissertation. We created two datasets: One was injected with two plagiarized paragraphs; the other was injected with multi-instances of plagiarized sentences. Both datasets went through preprocessing and segmentation into n-grams of strings as discussed in the previous section. The value of $n$ has been set to $2-7 \mathrm{~g}$. Table 8 shows the characteristics of the three datasets in the untampered form, with plagiarized paragraphs, and with plagiarized sentences. The count column lists the frequency of occurrence of the n-gram segments, the unique count column lists the frequency of such segments when repeated sequences are excluded.

\section{Experiment I: plagiarism detection in the original dataset}

The first experiment ran the plagiarism detection system through the untampered test dataset in six iterations of segmentation: 2-gram, 3-gram, 4-gram, 5-gram, 6-gram, and 7 -gram segmentation. It ran it against the "Sociology and Anthropology" subcorpus (cf. Table 8). The success rate of plagiarism detection for a dissertation $(D)$ is calculated by Eq. 1.

$$
\text { Reported Plag }{ }_{D}=\frac{\text { detected plagiarized unique } n \text {-grams in } D}{\text { all unique } n-\text { grams in } D} \times 100 \%
$$

The PD system labeled as 'plagiarized' (256) out of the (586) bigrams in the untampered test dataset (i.e., 43.68\%) (cf. Table 8). Table 9 shows samples of the bigram segments that were labeled as 'plagiarized'. The first column lists the titles of the source

Table 10 Detected trigram segments

\begin{tabular}{|c|c|c|c|}
\hline Title of Dissertation & Detected Trigrams & English Translation & Frequency \\
\hline ميرتون النظرية البنائية الوظيفية والتركيز على إسهامات روبرت & السياسية والاقتصادية والاجتماعية & $\begin{array}{l}\text { Political, economical } \\
\text { and social }\end{array}$ & 3 \\
\hline مشكلات المر أة الصحفية العاملة في الصحف اليومية الأردنية & السياسية و الاقتصادية والاجتماعية & $\begin{array}{l}\text { Political, economical } \\
\text { and social }\end{array}$ & 1 \\
\hline 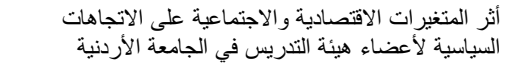 & الظروف الاقتصادية و الاجتماعية & $\begin{array}{l}\text { Economical } \\
\text { and social conditions }\end{array}$ & 1 \\
\hline 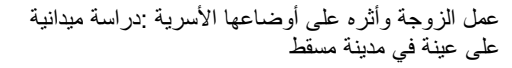 & جاءت العو امل الاقتصادية & Economical factors were & 1 \\
\hline
\end{tabular}



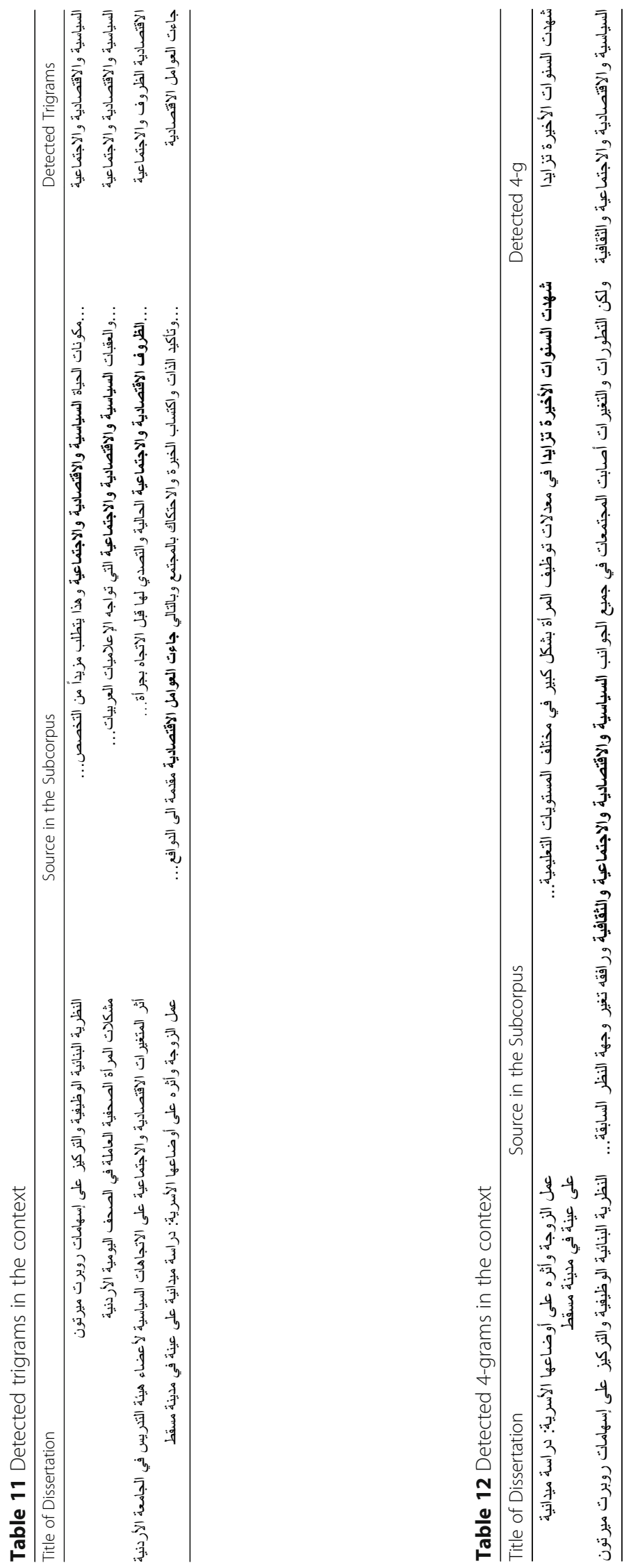
Table 13 Results of experiment I: plagiarism-labeling in the untampered test dataset

\begin{tabular}{lllll}
\hline $\begin{array}{l}\text { N-gram } \\
\text { Segments }\end{array}$ & $\begin{array}{l}\text { Retrieved } \\
\text { Dissertations }\end{array}$ & $\begin{array}{l}\text { Segments in the } \\
\text { Test Dataset }\end{array}$ & $\begin{array}{l}\text { Segments Identified } \\
\text { as Plagiarized }\end{array}$ & $\begin{array}{l}\text { Reported } \\
\text { Plagiarism Ratio }\end{array}$ \\
\hline 3 & 4 & 618 & 15 & $2.43 \%$ \\
4 & 2 & 624 & 2 & $0.32 \%$ \\
5 & 0 & 627 & 0 & $0.00 \%$ \\
6 & 0 & 627 & 0 & $0.00 \%$ \\
7 & 0 & 626 & 0 & $0.00 \%$ \\
\hline
\end{tabular}

dissertations where the detected bigrams were found, the second lists the detected bigrams, and the last lists the frequency of occurrence of these bigrams in the respective dissertations.

Bigram matching, however, is of little significance as bigrams hardly ever express a complete thought. It is not unexpected for matches to be found between bigrams in different dissertations since most two-word strings hold general concepts. Therefore, bigram matches might not be indicative of direct verbatim plagiarism.

When the PD system ran through the trigram segments, it labeled (15) out of the (618) trigrams in the test dataset as instances of plagiarism, i.e., the reported plagiarism rate was $2.43 \%$ (cf. Table 8 ). They were found in four dissertations. Table 10 shows a sample of the detected trigram segments.

A closer look at the detected trigrams shows that they also denote general concepts (see Table 11). However, many scholars consider the similarity of $n$-gram segments of four or more consecutive words to be verbatim plagiarism and hence it must be labeled as such. For example, Hexham (2005) treated the similarity of strings of four consecutive words as plagiarism, Roig (1999) five words, and Sorokina, Gehrke, Warner, and Ginsparg (2006) seven words.

When the PD system ran through the 4-gram iteration of the test dataset, it labeled only (2) out of the (624) 4-gram segments as instances of plagiarism, i.e., the reported plagiarism rate was $0.32 \%$ (cf. Table 8). Table 12 shows the detected 4-gram plagiarism.

Again, the 4-gram segments express general concepts and they hardly constitute genuine plagiarism. Although, 5-gram strings according to Roig (1999) are considered a good starting point for potential plagiarism, in this first experiment we could not find in the "Sociology and Anthropology" subcorpus any suspicious segments of five, six or seven consecutive words. Table 13 summarizes the results of the first experiment.

This experiment has demonstrated that when there is no intended plagiarism, a PD system can still label short segments as 'plagiarized'; the shorter the segment is, the more susceptible it is to misidentification as an instance of plagiarism. Passing a verdict of 'plagiarized segments' should be left to the discretion of the human. The machine

Table 14 Plagiarism-simulated paragraphs injected in the original dataset

\begin{tabular}{|c|c|}
\hline $\begin{array}{l}\text { raph-1 } \\
\text { ed } \\
\text { ge1 }\end{array}$ & 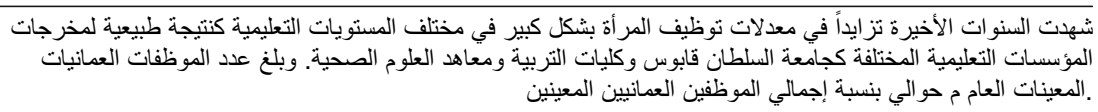 \\
\hline ragraph-2 & 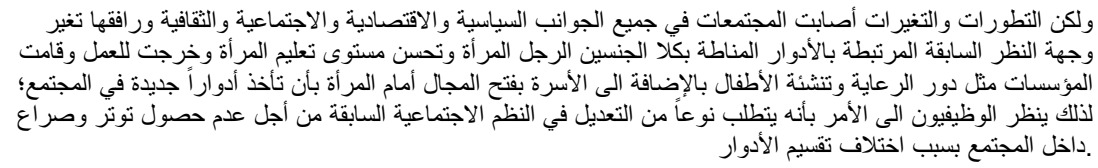 \\
\hline
\end{tabular}


Table 15 Results of the paragraph simulated-plagiarism experiment

\begin{tabular}{|c|c|c|c|c|c|}
\hline $\begin{array}{l}\text { N-gram } \\
\text { Segments }\end{array}$ & $\begin{array}{l}\text { Retrieved } \\
\text { Dissertations }\end{array}$ & $\begin{array}{l}\text { Segments in the } \\
\text { Test Dataset }\end{array}$ & $\begin{array}{l}\text { Segments with } \\
\text { Simulated Plagiarism }\end{array}$ & $\begin{array}{l}\text { Segments Identified } \\
\text { as Plagiarized }\end{array}$ & $\begin{array}{l}\text { Reported } \\
\text { Plagiarism Ratio }\end{array}$ \\
\hline 3 & 4 & 718 & 99 & 114 & $15.88 \%$ \\
\hline 4 & 2 & 725 & 97 & 99 & $13.93 \%$ \\
\hline 5 & 2 & 730 & 95 & 95 & $13.01 \%$ \\
\hline 6 & 2 & 731 & 93 & 93 & $12.72 \%$ \\
\hline 7 & 2 & 729 & 91 & 91 & $12.48 \%$ \\
\hline
\end{tabular}

can only point to the similarity it identified. Causes of this similarity, however, might be totally unrelated to plagiarism as demonstrated by the bigram and trigram detection.

\section{Experiment II: detecting paragraph simulated-plagiarism}

In the second experiment, the original test dataset was injected with two paragraphs extracted randomly from the "Sociology and Anthropology" subcorpus to simulate an act of plagiarism. The two paragraphs, shown in Table 14, were inserted into the first and second pages of the original test dataset. For the characteristics of the dataset with paragraph simulated-plagiarism see Table 8.

As established by the first experiment, bigram segments are too general to be considered as direct plagiarism. Hence, we ran the PD system through the test dataset with the two plagiarized paragraphs after segmenting it into the $3-7 \mathrm{~g}$ iterations.

The results of the second experiment are given in Table 15. The third column lists the number of segments after the insertion of the segments from the two plagiarismsimulated paragraphs (cf. Table 8). The fourth lists the number of n-gram segments that the plagiarized paragraphs consist of. The fifth lists the number of segments that the PD system labeled as 'plagiarized'. Notice that the values in the fifth column are higher than those in the fourth. The reason is that the PD system was able to detect all the simulated plagiarism and added the number of segments it had labeled as 'plagiarized' in the untampered dataset. For instance, the PD system labeled 114 as 'plagiarized' trigrams, 99 of which are trigrams in the plagiarism-simulating paragraphs and 15 trigrams labeled as 'plagiarized' in the original test dataset as explained in experiment I.

Table 16 Plagiarism-simulated sentences as injected in the original test dataset

\begin{tabular}{|c|c|c|}
\hline Plagiarism-simulated sentences & Page\# & Paragraph\# \\
\hline المتوسطات الحسابية والانحر افات المعيارية للكفاءة المعلوماتية لمكتبات & 1 & 1 \\
\hline الأنماط البنائية وحالاتها الائها & 1 & 2 \\
\hline و الانحر افات المعيارية للكفاءة التعليمية لمكتبات الددارس الأساسية & 1 & 3 \\
\hline و البالغ عددهم وطلبة المرحلة الأساسية العليا الصفوف & 1 & 4 \\
\hline أسئلة الدراسة استخر اج التكرارات و النسب & 2 & 1 \\
\hline 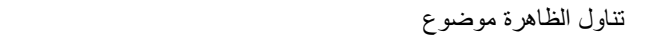 & 2 & 3 \\
\hline منطقية يجري بمقتضاها & 2 & 4 \\
\hline بصائر أحوال الظاهرة النحوية & 3 & 1 \\
\hline استخر اج التكرار ات و النسب المئوية والمتوسطات الحسابية و الانحر افات & 3 & 2 \\
\hline أهمية التحليل الحركي & 3 & 3 \\
\hline
\end{tabular}


Table 17 Results of experiment III where the dataset is injected with plagiarism-simulated sentences and run against the subcorpus

\begin{tabular}{llllll}
\hline $\begin{array}{l}\text { N-gram } \\
\text { Segments }\end{array}$ & $\begin{array}{l}\text { Retrieved } \\
\text { Dissertations }\end{array}$ & $\begin{array}{l}\text { Segments in the } \\
\text { Test Dataset }\end{array}$ & $\begin{array}{l}\text { Segments with } \\
\text { Simulated Plagiarism }\end{array}$ & $\begin{array}{l}\text { Segments Identified } \\
\text { as Plagiarized }\end{array}$ & $\begin{array}{l}\text { Reported } \\
\text { Plagiarism Ratio }\end{array}$ \\
\hline 3 & 4 & 662 & 28 & 15 & $2.27 \%$ \\
4 & 2 & 672 & 19 & 2 & $0.30 \%$ \\
5 & 0 & 673 & 13 & 0 & $0.00 \%$ \\
6 & 0 & 673 & 8 & 0 & $0.00 \%$ \\
7 & 0 & 672 & 4 & 0 & $0.00 \%$ \\
\hline
\end{tabular}

\section{Experiment III: detecting plagiarism-simulated sentences injected in the dataset}

In the third experiment, the original test dataset was injected with ten plagiarismsimulated sentences that were extracted randomly from the JUPlag corpus at large, rather than the "Sociology and Anthropology" subcorpus as the case was in the second experiment. The rationale was that we wanted to verify how our PD system would behave when the source of plagiarism is outside the scope of its corpus.

The ten plagiarized sentences are of variable word counts, 3 to 7 grams in length. They were appended to the original dataset in different paragraphs, with some injected on the first page, some on the second, and some on the third as shown in Table 16. For the characteristics of the new test dataset with plagiarism-simulated sentences, see Table 8. The PD system ran through this test dataset against the Sociology and Anthropology subcorpus.

A summary of the results of this experiment are in Table 17, where column 3 has the number of segments after insertion of the ten plagiarism-simulated sentences (cf. Table 8). In the next column are the number of n-grams that the plagiarized sentences consist of. Our PD system reports, in the last column, the plagiarism ratio as calculated by Eq. (1).

The table shows the PD system to have failed to detect any of the plagiarized n-gram segments of the sentences that were injected in the test dataset. The system, however, continued to label 15 trigrams and two of the 4-gram segments as 'plagiarized'. This is reminiscent of experiment I. This demonstrates that plagiarism from sources not covered by the PD corpus is likely to pass undetected.

To verify the efficiency of our PD system when the plagiarism lies within the scope of its corpus but without particularization of topic, the same experiment was run again but this time against the entire JUPlag corpus. It demonstrated that the system was perfectly capable of spotting plagiarized sentences even when the topic is not specified,

Table 18 Results of experiment III where the dataset is injected with plagiarism-simulated sentences and run against the entire corpus

\begin{tabular}{lllll}
\hline $\begin{array}{l}\text { N-gram } \\
\text { Segments }\end{array}$ & $\begin{array}{l}\text { Segments in } \\
\text { Test Dataset }\end{array}$ & $\begin{array}{l}\text { Segments with } \\
\text { Simulated Plagiarism }\end{array}$ & $\begin{array}{l}\text { Segments Identified } \\
\text { as Plagiarized }\end{array}$ & $\begin{array}{l}\text { Reported } \\
\text { Plagiarism Ratio }\end{array}$ \\
\hline 3 & 662 & 28 & 159 & $24.02 \%$ \\
4 & 672 & 19 & 57 & $8.48 \%$ \\
5 & 673 & 13 & 20 & $2.97 \%$ \\
6 & 673 & 8 & 11 & $1.63 \%$ \\
7 & 672 & 4 & 5 & $0.74 \%$ \\
\hline
\end{tabular}


Table 19 Samples of plagiarized n-gram segments

\begin{tabular}{|c|c|}
\hline N-gram Segments & Suspicious Plagiarism Sentences \\
\hline \multirow[t]{4}{*}{ 5-gram } & خلصت الدراسة مجمو عة التوصيات ابرزها \\
\hline & الدراسة مجمو عة التوصبات ابرز ها ضرورة \\
\hline & توصلت الدراسة مجموعة النتائج اهمها \\
\hline & شتى مجالات الحياة السياسية والاقتصادية \\
\hline \multirow[t]{2}{*}{ 6-gram } & اسئلة الدراسة نم استخر اج التكرارات و النسب \\
\hline & الدراسة تم استخر اج التكرارات و النسب المئوية \\
\hline 7-gram & المئوية اسئلة الدراسة تم استخر اج التكر ارات و النسب \\
\hline
\end{tabular}

provided that the plagiarized source is in its corpus. See Table 18 for a summary of results and Table 19 for a sample of identified plagiarism.

In addition, the PD system labeled more n-gram segments other than the ones reported in experiment I. For instance, the PD system labeled (159) plagiarized trigram segments in the test dataset. This number includes the plagiarism-simulated trigrams (28), the (15) trigrams segments labeled in the subcorpus from experiment I, in addition to (116) new trigrams segments detected in the entire JUPlag corpus.

Notice in Table 18 that the PD system identified exceedingly more than the injected trigrams and 4-gram segments, but beginning from 5-grams the plagiarism yield became more reasonable. This goes to support Roig's (1999) definition of plagiarism as "the appropriation of strings of five consecutive words or longer. (p.973)" since shorter n-gram segments hardly ever constitute propositions. Even with 5-, 6-, and 7-gram segments, the system overestimated plagiarism by seven, three, and one segment respectively. This distortion indicates that the longer the segment is, the more confident the identification.

\section{Conclusion and research directions}

We presented above a plagiarism detection corpus built for Arabic and designed especially for academic purposes. JUPlag is organized in accordance with the Dewey classification system and is guided by the metadata adopted by the Library of the University of Jordan. Although this corpus is still under construction, research on Arabic that is carried out by the international community may benefit from it. It can use it in its current state for the detection of plagiarism in Arabic dissertations and articles prior to final submission. It can also be beneficial for the development of new plagiarism detection tools. It may also be used for corpus-based and corpus-driven linguistic analyses, for language learning and teaching, for lexicography, and for teaching research methodology. We showed here the stages of corpus construction and the challenges encountered. To test the reliability of the corpus and PD system, we conducted a set of experiments with multi-instances of plagiarismsimulated paragraphs and sentences deliberately injected in a test dataset. Experimental results proved both the corpus and the system to be quite efficient in detecting n-gram verbatim plagiarism. It has been demonstrated here that it is indispensable for an extrinsic plagiarism detection system to have an authentic, big, versatile, properly classified and richly annotated reference corpus. It has also been confirmed that verbatim plagiarism detection is only reliable when the similaritymatching unit is longer than 4-g. In the next phase of this project, the reference 
corpus will be expanded to encompass all the dissertations in the Thesis Repository of the Union of Arab Universities. The PD system will also utilize a variety of plagiarism detection techniques. Future research may focus on the expansion and representativeness of the corpus; the bigger the corpus and the more representative it is of disciplines in the humanities and social sciences, the more efficient plagiarism detection will be. Detection may also be complemented by the use of intrinsic, machine learning, and deep machine learning techniques.

\section{Abbreviations}

2 L-APD: Two-Level Plagiarism Detection System; AraPlagDet: Arabic Plagiarism Detection; ASCll: American Standard Code for Information Interchange; BKDR: Brian Kernighan and Dennis Ritchie; CNN: Convolutional Neural Network; DDC: Dewey decimal classification; EPD: Extrinsic plagiarism detection; ExAraPlagDet: External Arabic Plagiarism Detection; HYPLAG: Hybrid Plagiarism; IPD: Intrinsic plagiarism detection; IR: Information Retrieval; JU: The University of Jordan; JUPlag: Jordan University Plagiarism corpus; LCS: Longest Common Substring; MADAMIRA: Morphological Analysis and Disambiguation of Arabic; NLP: Natural Language Processing; OSAC: Open Source Arabic Corpus; PAN@FIRE: PAN-Forum for Information Retrieval Evaluation; PD: Plagiarism detection; PDS: Plagiarism detection software; POST: Part-of-speech tagger; TF*IDF: Term Frequency-Inverse Document Frequency

\section{Acknowledgments}

The authors would like to thank the director of the JU library, Dr. Nashrawan Al-Tahat and her IT staff for giving us restricted access to the dissertation repository and for providing the necessary computing facilities for the development and analysis of the JUPlag corpus and for permission to experiment with our PD system.

\section{Authors' contributions}

This research is part of a dissertation research conducted by the first author, EA-T. All authors read and approved the final manuscript.

\section{Funding}

Data collection is funded by the JU Library as part of the doctoral program collaboration.

\section{Availability of data and materials}

The datasets generated and/or analyzed during the current study are not publicly available due to JU copyright policy but are available from the corresponding author on reasonable request.

\section{Competing interests}

The authors declare that they have no competing interests.

\section{Author details}

${ }^{1}$ Computer Science Department, King Abdullah II School of Information Technology, University of Jordan, Amman, Jordan. ${ }^{2}$ Computer Information Systems Department, King Abdullah II School of Information Technology, University of Jordan, Amman, Jordan. ${ }^{3}$ Department of Foreign Languages, College of Arts, University of Sharjah, Sharjah, United Arab Emirates.

Received: 17 May 2019 Accepted: 20 November 2019

Published online: 16 January 2020

\section{References}

Abdelrahman, Y. A., Khalid, A., \& Osman, I. M. (2017). A method for Arabic documents plagiarism detection. International Journal of Computer Science and Information Security, 15(2), 79.

AlSallal, M., Iabal, R., Palade, V., Amin, S., \& Chang, V. (2019). An integrated approach for intrinsic plagiarism detection. Future Generation Computer Systems, 96, 700-712.

Baba, K., Nakatoh, T., \& Minami, T. (2017). Vector representation of words for plagiarism detection based on string matching. In International conference on human interface and the management of information, (pp. 341-350). Cham: Springer.

Bensalem, I., Boukhalfa, I., Rosso, P., Abouenour, L., Darwish, K., \& Chikhi, S. (2015). Overview of the AraPlagDet PAN@ FIRE2015 shared task on Arabic plagiarism detection. In FIRE workshops, (pp. 111-122).

Beute, N., Van Aswegen, E. S., \& Winberg, C. (2008). Avoiding plagiarism in contexts of development and change. IEEE Transactions on Education, 51(2), 201-205.

Bolkan, J. V. (2006). Avoid the plague: Tips and tricks for preventing and detecting plagiarism. Journal of Vocational Education and Training, 33, 4-14.

Chan, L. M., Comaroni, J. P., Mitchell, J. S., \& Satija, M. P. (1996). Dewey decimal classification: A practical guide. Albany: Forest Press.

Coxhead, A. (2000). A new academic word list. TESOL Quarterly, 34(2), 213-238.

Devlin, M., \& Gray, K. (2007). In their own words: A qualitative study of the reasons Australian university students plagiarize. High Education Research \& Development, 26(2), 181-198.

DeVoss, D., \& Rosati, A. C. (2002). It wasn't me, was it? Plagiarism and the Web. Computers and Composition, 19(2), 191-203.

Elhadi, M., \& Al-Tobi, A. (2008). Use of text syntactical structures in detection of document duplicates. In Third international conference on digital information management, (pp. 520-525). London, UK. 
Eret, E., \& Ok, A. (2014). Internet plagiarism in higher education: Tendencies, triggering factors and reasons among teacher candidates. Assessment \& Evaluation in Higher Education, 39(8), 1002-1016.

Fister, B. (2009). The Dewey dilemma. Library Journal, 134(16), 22-25.

Franklin-Stokes, A., \& Newstead, S. (1995). Undergraduate cheating: Who does what and why? Studies in Higher Education, 20(2), 159-172.

Frye, B. L. (2016). Plagiarism is not a crime. Duquesne University Law Review, 54, 133 https://uknowledge.uky.edu/law_ facpub/532. Visited 30 Mar 2019.

Ghanem, B., Arafeh, L., Rosso, P., \& Sánchez-Vega, F. (2018). HYPLAG: Hybrid Arabic text plagiarism detection system. In International conference on applications of natural language to information systems, (pp. 315-323). Cham: Springer.

Gipp, B., \& Beel, J. (2010). Citation based plagiarism detection: A new approach to identify plagiarized work language independently. In Proceedings of the 21st ACM conference on hypertext and hypermedia, (pp. 273-274). Toronto, Canada.

Gipp, B., \& Meuschke, N. (2011). Citation pattern matching algorithms for citation-based plagiarism detection: Greedy citation tiling, citation chunking and longest common citation sequence. In Proceedings of the 11th ACM symposium on Document engineering, (pp. 249-258). Mountain View, California, USA.

Golub, K., Lykke, M., \& Tudhope, D. (2014). Enhancing social tagging with automated keywords from the Dewey decimal classification. Journal of Documentation, 70(5), 801-828.

Hammo, B., Yagi, S., Ismail, O., \& AbuShariah, M. (2016). Exploring and exploiting a historical corpus for Arabic. Language Resources and Evaluation, 50(4), 839-861.

Hexham, I. (2005). Academic plagiarism defined. Department of Religious Studies, University of Calgary http://people.ucalgary. $\mathrm{ca/}$ hexham/content/articles/plague-of-plagiarism.html. Visited 30 Mar 2019.

Jenkins, C., Jackson, M., Burden, P., \& Wallis, J. (1998). Automatic classification of web resources using Java and Dewey decimal classification. Computer Networks and ISDN Systems, 30(1-7), 646-648.

Khoja, S., \& Garside, R. (1999). Stemming Arabic text. Lancaster, UK, Computing Department, Lancaster University.

Khorsi, A., Cherroun, H., \& Schwab, D. (2018). 2L-APD: A two-level plagiarism detection system for Arabic documents. Cybernetics and Information Technologies, 18(1), 124-138.

Kong, L., Zhao, Z., Lu, Z., Qi, H., \& Zhao, F. (2016). A method of plagiarism source retrieval and text alignment based on relevance ranking model. International Journal of Database Theory and Application, 9(12), 35-44.

Leonardo, B., \& Hansun, S. (2017). Text documents plagiarism detection using Rabin-Karp and Jaro-Winkler distance algorithms. Indonesian Journal of Electrical Engineering and Computer Science, 5(2), 462-471.

Lukashenko, R., Graudina, V., \& Grundspenkis, J. (2007). Computer-based plagiarism detection methods and tools: An overview. In Proceedings of the 2007 international conference on computer systems and technologies, (p. 40). Rousse, Bulgaria.

Mahmoud, A., Zrigui, A., \& Zrigui, M. (2017). A text semantic similarity approach for Arabic paraphrase detection. In International conference on computational linguistics and intelligent text processing, (pp. 338-349). Cham: Springer.

Mahmoud, A., \& Zrigui, M. (2017). Semantic similarity analysis for paraphrase identification in Arabic texts. In Proceedings of the 31st Pacific Asia conference on language, information and computation, (pp. 274-281).

Maurer, H. A., Kappe, F., \& Zaka, B. (2006). Plagiarism-A survey. Journal of Universal Computer Science, 12(8), 1050-1084.

Meuschke, N., Gipp, B., Breitinger, C., \& Berkeley, U. (2012). CitePlag: A citation-based plagiarism detection system prototype. In Proceedings of the 5 th international plagiarism conference. Newcastle upon Tyne, UK.

Meuschke, N., Siebeck, N., Schubotz, M., \& Gipp, B. (2017). Analyzing semantic concept patterns to detect academic plagiarism. In Proceedings of the 6th international workshop on mining scientific publications, (pp. 46-53). Toronto, Canada.

Nakatoh, T., Baba, K., Yamada, Y., \& Ikeda, D. (2011). Partial plagiarism detection using string matching with mismatches. In International conference on informatics engineering and information science, (pp. 265-272). Berlin: Springer.

Paul, M., \& Jamal, S. (2015). An improved SRL based plagiarism detection technique using sentence ranking. Procedia Computer Science, 46, 223-230.

Polydouri, A., Siolas, G., \& Stafylopatis, A. (2017). Intrinsic plagiarism detection with feature-rich imbalanced dataset learning. In International conference on engineering applications of neural networks, (pp. 99-110). Cham: Springer.

Rahman, R. (2015). Information theoretical and statistical features for intrinsic plagiarism detection. In Proceedings of the SIGDIAL 2015 conference, Prague, Czech Republic, (pp. 144-148).

Roig, M. (1999). When college students' attempts at paraphrasing become instances of potential plagiarism. Psychological Reports, 84(3), 973-982.

Ruipérez, G., \& García-Cabrero, J.-C. (2016). Plagiarism and academic integrity in Germany. Comunicar: Media Education Research Journal, 24(48), 9-17. https://doi.org/10.3916/C48-2016-01.

Saad, M. K., \& Ashour, W. M. (2010). Osac: Open source arabic corpora. In The 6th international conference on electrical and computer systems (EECS'10), Lefke, North Cyprus.

Salton, G., \& Buckley, C. (1988). Term-weighting approaches in automatic text retrieval. Information Processing and Management, 24, 513-523.

Sapir, E., \& Swiggers, P. (2008). General linguistics, (vol. 1). Walter de Gruyter. Berlin, New York.

Satija, M. P., \& Martínez-Ávila, D. (2019). Plagiarism: An essay in terminology. DESIDOC: Journal of Library \& Information Technology, 39(2), 87-93. https://doi.org/10.14429/djlit.39.2.13937.

Si, A., Leong, H. V., \& Lau, R. W. (1997). Check: A document plagiarism detection system. In SAC, (vol. 97, pp. 70-77).

Sorokina, D., Gehrke, J., Warner, S., \& Ginsparg, P. (2006). Plagiarism detection in arXiv. In Proceedings of the sixth international conference on data mining, (pp. 1070-1075) Available at http://arxiv.org/abs/cs/0702012. Visited 30 Mar 2019.

Tschuggnall, M., \& Specht, G. (2012). Plag-inn: Intrinsic plagiarism detection using grammar trees. In International conference on application of natural language to information systems, (pp. 284-289). Berlin: Springer.

Vani, K., \& Gupta, D. (2017). Text plagiarism classification using syntax based linguistic features. Expert Systems with Applications, 88, 448-464.

Velupillai, V. (2012). An introduction to linguistic typology. John Benjamins Publishing. Amsterdam, The Netherlands.

Vij, R., Soni, N. K., \& Makhdumi, G. (2009). Encouraging academic honesty through anti-plagiarism software. In Proceedings of the 7th international CALIBER, Pondicherry University, (pp. 439-448). 
Wise, M. J. (1996). YAP3: Improved detection of similarities in computer program and other texts. ACM SIGCSE Bulletin, 28(1), 130-134 ACM.

Yang, Y. M. (1995). Noise reduction in a statistical approach to text categorization. In Proceedings of SIGIR-95, 18th ACM international conference on research and development in information retrieval, (pp. 256-263).

Zaher, M., Shehab, A., Elhoseny, M., \& Osman, L. (2017). A new model for detecting similarity in Arabic documents. In International conference on advanced intelligent systems and informatics, (pp. 488-499). Cham: Springer.

Zu Eissen, S. M., \& Stein, B. (2006). Intrinsic plagiarism detection. In European conference on information retrieval, (pp. 565-569). Berlin: Springer.

\section{Publisher's Note}

Springer Nature remains neutral with regard to jurisdictional claims in published maps and institutional affiliations.

Submit your manuscript to a SpringerOpen ${ }^{\odot}$ journal and benefit from:

- Convenient online submission

- Rigorous peer review

- Open access: articles freely available online

- High visibility within the field

- Retaining the copyright to your article

Submit your next manuscript at $\boldsymbol{\nabla}$ springeropen.com 